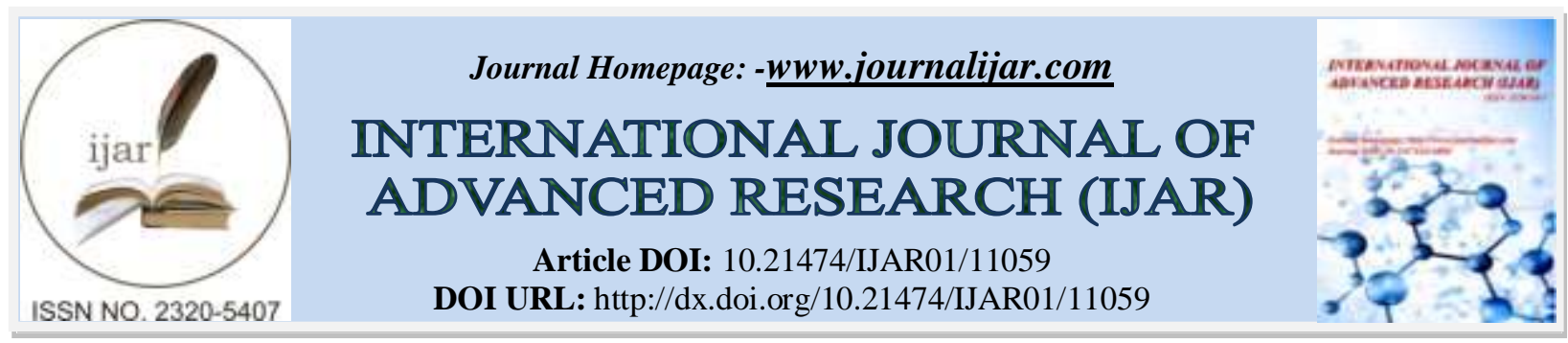

RESEARCH ARTICLE

\title{
ANTIBIOTIC SUSCEPTIBILITY OF MICROBIAL CONTAMINANTS FOUND IN COMMERCIALLY AVAILABLE QUININE SYRUPS AND INJECTION WATERS SOLD IN OWERRI, IMO STATE NIGERIA
}

Prof. E.S Amadi, Prof. C.E Nwanyanwu and F.C. Mbata
Department of Microbiology, School of Biological Science, Postgraduate School, Federal University of Science and Technology.

\section{Manuscript Info}

Manuscript History

Received: 01 April 2020

Final Accepted: 05 May 2020

Published: June 2020

\section{Abstract}

Antimicrobial susceptibility tests were carried out on bacteria isolated from quinine syrups and water for injections. Bactria isolates from quinine syrups and injection water samples were identified as Bacillus $s p$. and Staphylococcus sp. and are designated as Bacillus sp. 2S2 and Staphylococcus sp. 2S3 for quinine samples and Bacillus sp. 2W1 and Staphylococcus sp. $3 \mathrm{~W} 3$ for the injection water samples. The susceptibility test was carried out using the Mueller-Hinton broth dilution method supplemented with $0.1 \%(\mathrm{w} / \mathrm{v})$ of tetrazolium chloride as an indicator dye at $37^{\circ} \mathrm{C}$ and also the Mueller-Hinton agar disk diffusion method supplemented with $0.1 \%(\mathrm{w} / \mathrm{v})$ of tetrazolium chloride indicator dye. Four different antibiotics including Ofloxacin, Cefixime, Ciprofloxacin and Levofloxacin were used at different concentrations range of $0-1000 \mu \mathrm{g} / \mathrm{ml}$ for Ofloxacin and Cefixime and $0-2000 \mu \mathrm{g} / \mathrm{ml}$ for ciprofloxacin and Levofloxacin. Ofloxacin showed a higher inhibition on the Staphylococcus sp. 2S3 and Bacillus sp. 2S2 than the Bacillus sp. 2W1 and Staphylococcus sp. 3W3, while Ciprofloxacin, Levofloxacin and Cefixime showed a higher inhibition on Bacillus sp. The minimum inhibitory concentrations (MIC) of each of the antibiotics were estimated by application of $\mathrm{IC}_{50}$ using macrobroth dilution procedure. Out of the 20 analysed samples of quinine and 10 injection waters, 17 quinine syrups and 8 injection waters were contaminated.

Copy Right, IJAR, 2020,. All rights reserved.

\section{Introduction:-}

Malaria has been a leading source of mortality, and morbidity for Nigerian children particularly for under 5-year-old (Mojekwu and Ajilola, 2011). Consequently, adequate disease management in primary health care units is the basis for malaria control which is in line with national and global malaria control strategies (Toure, 2001). On the other hand, accurate diagnosis and treatment cannot be overemphasized for effective malaria control. Quinine is a drug of choice for the treatment of Plasmodium falciparum malaria. Quinine is subject to microbial contaminations, which may ultimately contribute to secondary bacterial infections, especially as the immune system of children is immature (Nester, et al., 2002). the use of intramuscular quinine in children may cause an abscess, and therefore, this route of administration is discouraged (Barenneset al., 1996).

\section{Corresponding Author:- Prof. E.S Amadi}

Address:- Department of Microbiology, School of Biological Science, Postgraduate School, Federal University of Science and Technology. 
As a result of its characteristic bitter taste, quinine is preferably used in children in the form of syrup (Centre for Disease Control, 1991) but poorly prepared quinine syrups are subject to microbial contaminations. Quinine occurs naturally in the bark of the cinchona tree, though it has also been synthesized in the laboratory.

Water for Injection is purified by distillation or a purification process that is equivalent or superior to distillation in the removal of chemicals and microorganisms. It is prepared from water complying with the U.S. Environmental Protection Agency, National Primary Drinking Water Regulations or with the drinking water regulations of the European Union or of Japan or with the World Health Organization's Guidelines for Drinking Water Quality or Standard Organisation of Nigeria or National Agency for Food and Drug Administration and Control. It contains no added substance. Water for Injection is intended for use in the preparation of parenteral solutions. Where used for the preparation of parenteral solutions subject to final sterilization, use suitable means to minimize microbial growth, or first render the Water for Injection sterile and, thereafter, protect it from microbial contamination. WFI is not sterile water and is not a final dosage form. It is an intermediate bulk product. WFI is the highest quality of pharmacopeia water for pharmaceutical use (WPU), (WHO, 2003).

2, 3, 5-Triphenyl tetrazolium chloride (TTC) is a redox indicator used as an indicator of microbial respiration as well as viability. A bacterial cell that is actively respiring reduces TTC from water-soluble, colorlesstetrazolium salt to a water-insoluble red formazan product. Rich et al. (2001) have shown that TTC is primarily reduced by Complex I in mitochondria, and complete reduction to TTC-formazan only occurs under anaerobic conditions as the initial reduction product, presumably, a TTC radical intermediate, is rapidly re-oxidized by molecular oxygen.

The formazan accumulates in the cells and can be extracted by the use of certain organic solvents such as; ethyl acetate, butanol or amyl alcohol. A spectrophotometer is used to determine the absorbance of the extract (Friedelet al., 1994). Although sterility is not a requirement in official compendia for non-sterile pharmaceuticals, bio burdens need to be within acceptable limits $\left(10^{3} \mathrm{CFU} / \mathrm{ml}\right)$. (Conn, 1975, FIP working party, 1975).

\section{Materials And Methods:- Sample Collection}

The Quinine syrup and Water for injection samples were purchased at pharmaceutical stores in Owerri, Imo State Nigeria. A total of 20 samples of quinine syrups and 10 samples of injection waters were analyzed.

\section{Isolation of Organisms}

Ten-fold serial dilution technique was carried on the Quinine syrup and Injection Water samples. This involved aseptically transferring $1 \mathrm{ml}$ of the syrup and injection water into $9 \mathrm{ml}$ of sterile normal saline contained in a sterile screw-capped glass test tube $(20 \mathrm{ml}), 1 \mathrm{ml}$ of the content of this tube was then transferred to another tube containing $9 \mathrm{ml}$ of sterile normal saline. This was subsequently repeated up to $10-^{6}$ dilution.

Using spread plate techniques, $0.1 \mathrm{ml}$ of the content of the $10-^{6}$ tube was inoculated onto a nutrient agar plate, using a sterile glass spreader; the inoculums were spread on the surface of the agar. The plates were then incubated for 48hours at a temperature of $37^{\circ} \mathrm{C}$. Growth was observed, enumerated and recorded as colony-forming unit per milliliter $(\mathrm{CFU} / \mathrm{ml})$

\section{Purification of the Isolates}

The organisms isolated from the Quinine syrup and Water for Injection samples were streaked onto fresh nutrient agar plates to remove any carryover. The plates were incubated for $24 \mathrm{~h}$ and thereafter sub-cultured on agar slants and stored in a refrigerator at $40 \mathrm{C}$.

\section{Screening of Isolates for 2, 3, 5-triphenyl tetrazolium Chloride (TTC) Reduction}

The organisms isolated from the quinine syrup and injection water samples were screened for their ability to reduce TTC to triphenylformazan as described by Nwanyanwu and Abu 2012. This was done by inoculating the different cultures obtained onto fresh nutrient agar plates and incubated for $24 \mathrm{~h}$. After the incubation, an aqueous solution of $0.1 \%$ of TTC was spread on the surface of the culture plates after 10 fold serial dilutions. The plates were further incubated in the dark at room temperature for $24 \mathrm{hr}$ and then observed for the color change to red which indicates the reduction of TTC to formazan. Plates showing high red coloration were selected and then identified by carrying out a series of biochemical tests. 


\section{Preparation of Standard Calibration Curve of Formazan}

In a small quantity of amyl alcohol, $0.1 \mathrm{~g}$ of dry formazan was dissolved and made up $100 \mathrm{ml}$ amyl alcohol to give $1000 \mu \mathrm{g} / \mathrm{ml}$ of formazan stock solution. From the stock solution, graded concentrations of the formazan were prepared using the protocol shown in Table 3.1. The absorbance of the standard solutions was measured with a spectrophotometer at $500 \mathrm{~nm}$ wavelength. A graph of absorbance against concentration was then plotted and is shown in Appendix

\section{Antimicrobial agents}

Different antibiotics were used but the particular reference was made to these because of their sensitivity; Ofloxacin (200mg), Cefixime (200mg), Ciprofloxacin (500mg), Levofloxacin (500mg), etc.

\section{Preparation of antibiotic stock}

Ofloxacin and Cefixime were dissolved in respective $250 \mathrm{ml}$ volumetric flasks with little sterile water and made up to $100 \mathrm{ml}$ to obtain $2000 \mu \mathrm{g} / \mathrm{ml}$ of the stock solution of the Ofloxacin and Cefixime. The same was carried out on Ciprofloxacin and Levofloxacin to obtain $5000 \mu \mathrm{g} / \mathrm{ml}$ of stock solution. From there, the antibiotic stock solutions were diluted to various concentrations as shown in Table 3.2 and Table 3.3.

\section{Preparation of Inoculum}

The isolates were grown in nutrient broth on a rotary shaker (150rpm) at room temperature $(28 \pm 20 \mathrm{C})$. After $24 \mathrm{~h}$, the cells were harvested by centrifugation (ALPIN MEDICAL ENGLAND 90(1)) at 4000rpm for 10min.

Harvested cells were washed twice in sterile distilled water to ensure that there is no leftover of nutrient broth (Nwekeet al., 2007). The washed cells were suspended in the same medium and their optical density (OD) adjusted to 0.5 at a wavelength of $540 \mathrm{~nm}$ using spectrophotometer (VIS Spectrophotometer 721D, Life Assistance Scientific INST. CO).

\section{Estimation of the dry weight of the isolates}

The dry weight of the organisms was estimated by adding $10 \mathrm{ml}$ of the standardized cells into previously air dried, weighed $20 \mathrm{ml}$ beaker. The beakers containing the suspended cells were then placed in an oven at $80^{\circ} \mathrm{C}$ and left to dry to a constant weight. The beakers were weighed again and the previous weight of the beaker when it was empty was subtracted from the new weight, the result was recorded as the dry weight of the organism (Chapin and Lauderdale, 2003). The standardized cell suspensions served as inoculum for the antibiotic susceptibility tests.

\section{Broth Microdilution Susceptibility Test Using TTC}

The assay was done in a $3 \mathrm{ml}$ final volume solution which contained $1 \mathrm{ml}$ of triple strength Mueller-Hinton broth, the varying volume of the antibiotic stock, $0.3 \mathrm{ml}$ of the standardized test organism, $0.1 \mathrm{ml} \mathrm{of} 1 \mathrm{mg} / \mathrm{ml} \mathrm{TTC}$ and sterile water was used to make up the volume to $3 \mathrm{mls}$. The final concentration of the antibiotics ranged from $0-1000 \mu \mathrm{g} / \mathrm{ml}$ for Ofloxacin and Cefixime; and 50-2000 $\mathrm{g} / \mathrm{ml}$ for the Ciprofloxacin and Levofloxacine. Controls that do not contain any antibiotics were set up and treated as others. An uninoculated control tube, served for contamination control, indicated by an absence of color change was also set up. The tubes were statically incubated in the dark for $24 \mathrm{~h}$. Thereafter, the tubes were observed for the formation of red color which indicates the formation of TriphenylFormazan. The minimum inhibitory concentration of the antibiotics was the lowest concentration of the antibiotic that did not yield the red formazan coloration (NCCLS, 1997).

The TriphenylFormazan (TPF) produced was then extracted by adding $4 \mathrm{ml}$ of amyl alcohol to each of the tubes and shaking vigorously for one minute. Using a spectrophotometer, the absorbance of the extracted solution was done at $500 \mathrm{~nm}$ wavelength. The amount of formazan produced was estimated by reference to a standard calibrated curve. Dehydrogenase activity of the isolates was expressed as microgram of TPF formed per milligram dry weight of the cell biomass per hour.

\section{Results And Discussion:- \\ Isolates}

The morphological and biochemical characteristics of the bacterial isolates from the Quinine syrup and Water for injection are shown in Tables 4.1 to 4.4. The test organisms were identified as Bacillus sp. 2S2, Bacillus sp. 2W1, Staphylococcus sp. 2S3 and Staphylococcus sp. 3W3. S is designated as microorganisms from quinine samples while $\mathrm{W}$ is for microorganisms isolated fromInjection water. 

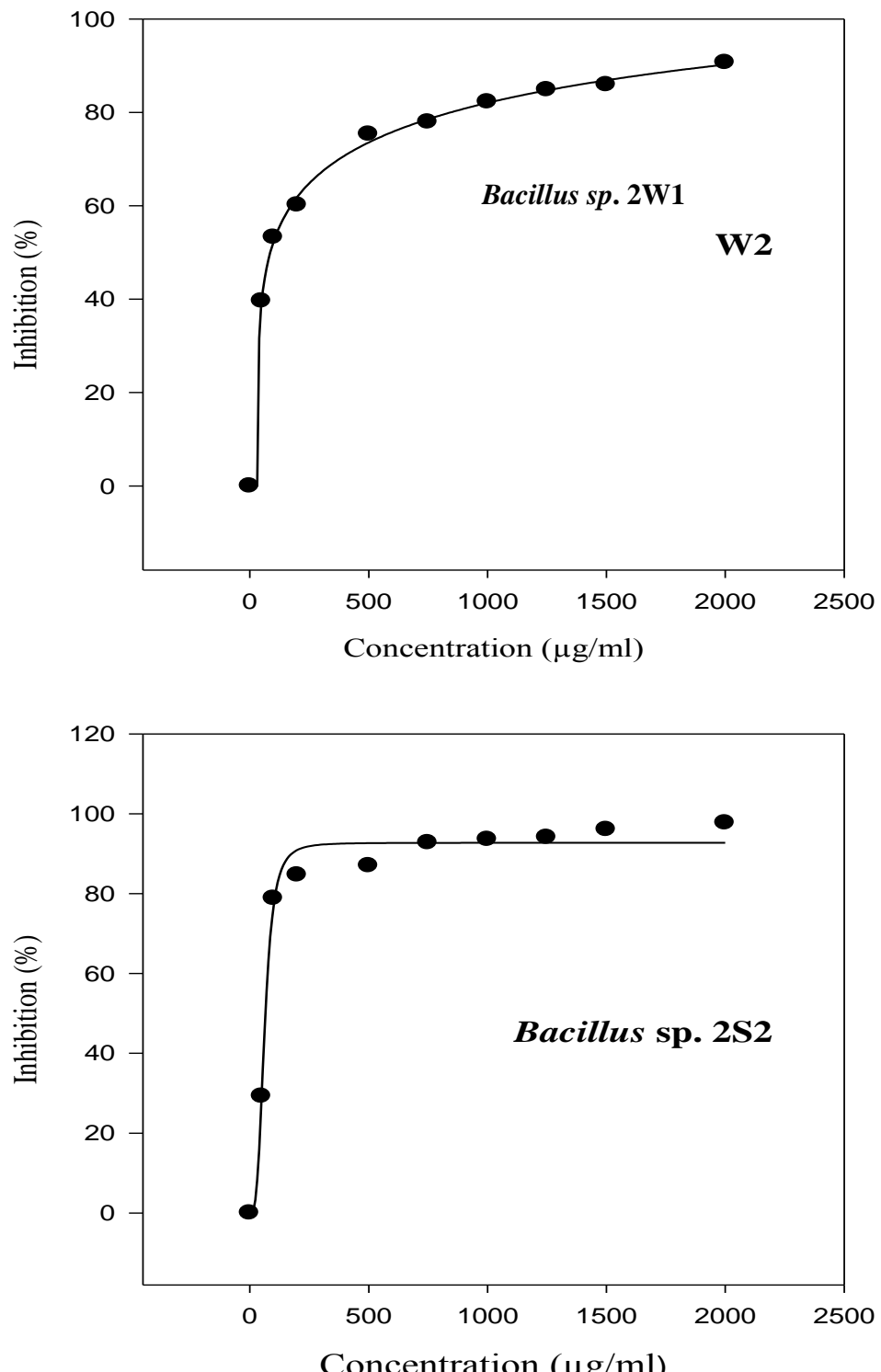

Figure 4.1:- Inhibition of dehydrogenase activity of Bacillus species $2 \mathrm{~S} 2$ from Quinine syrup and Bacillus species $2 \mathrm{~W} 1$ from injection water by Ofloxacin. 

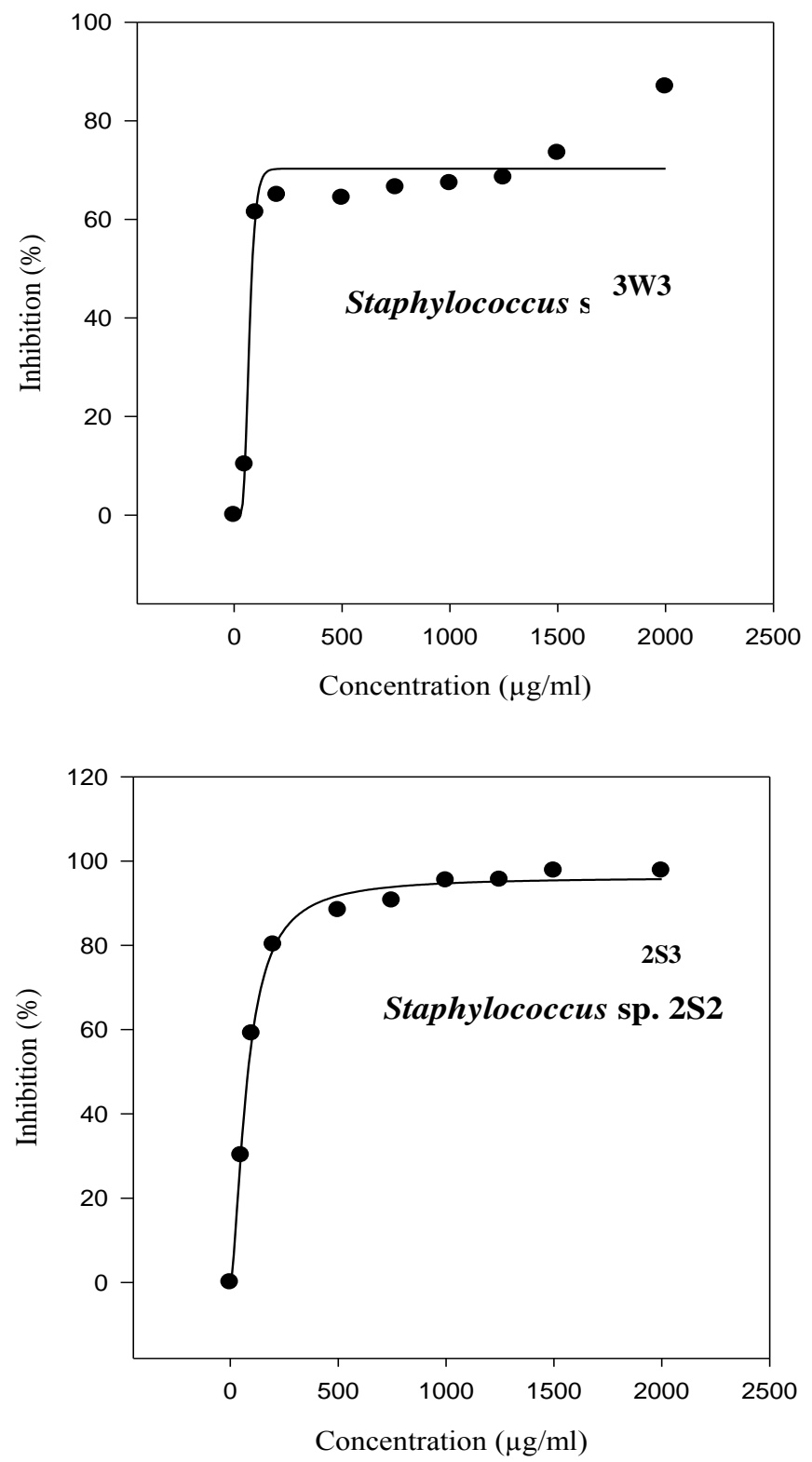

Figure 4.2:- Inhibition of dehydrogenase activity of Staphylococcus species 2S3 from Quinine syrup and Staphylococcus species $3 \mathrm{~W} 3$ from injection water by Ofloxacin. 

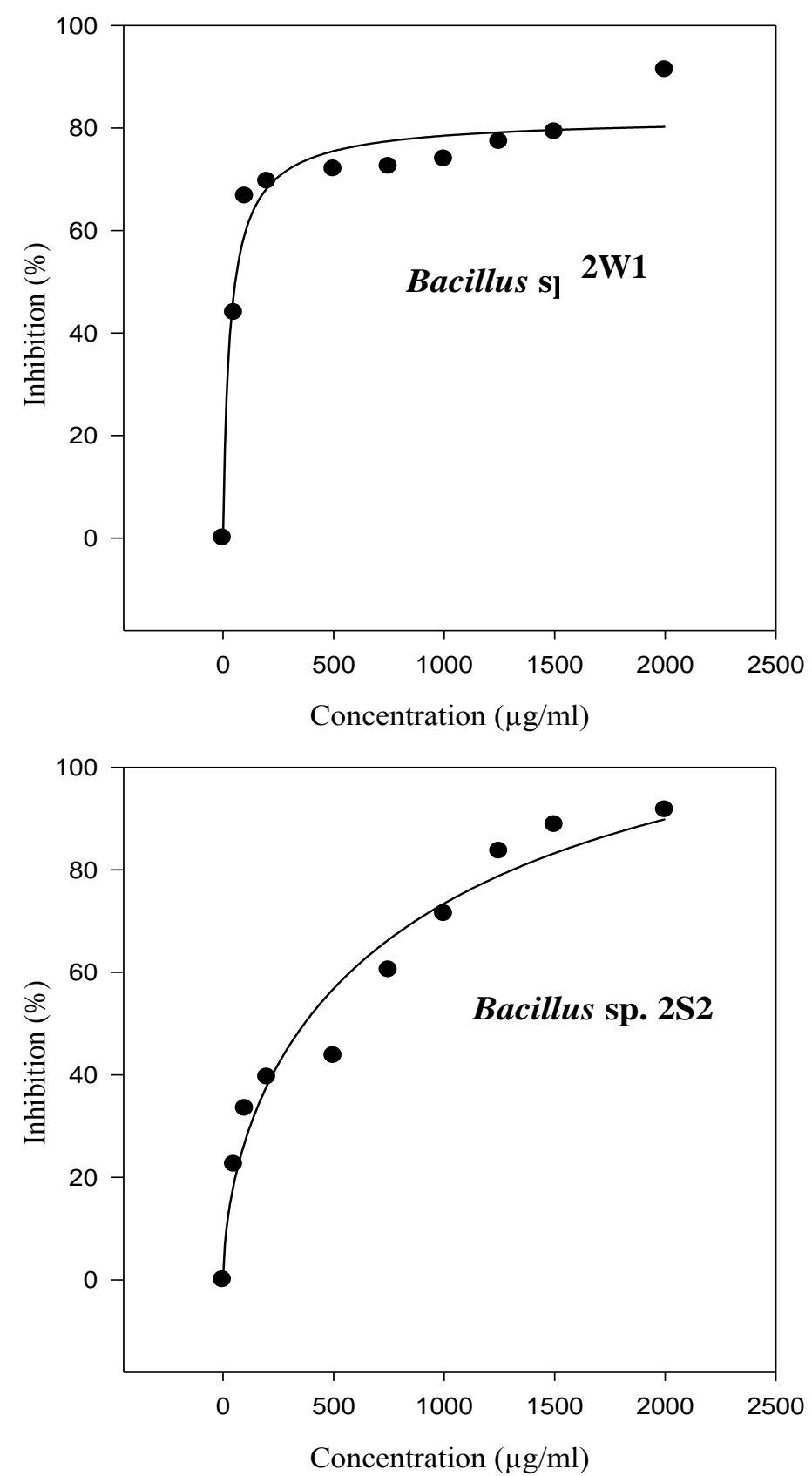

Figure 4.3:- Inhibition of dehydrogenase activity of Bacillus species $2 \mathrm{~S} 2$ from Quinine syrup and Bacillus species $2 \mathrm{~W} 1$ from injection water by cefixime. 

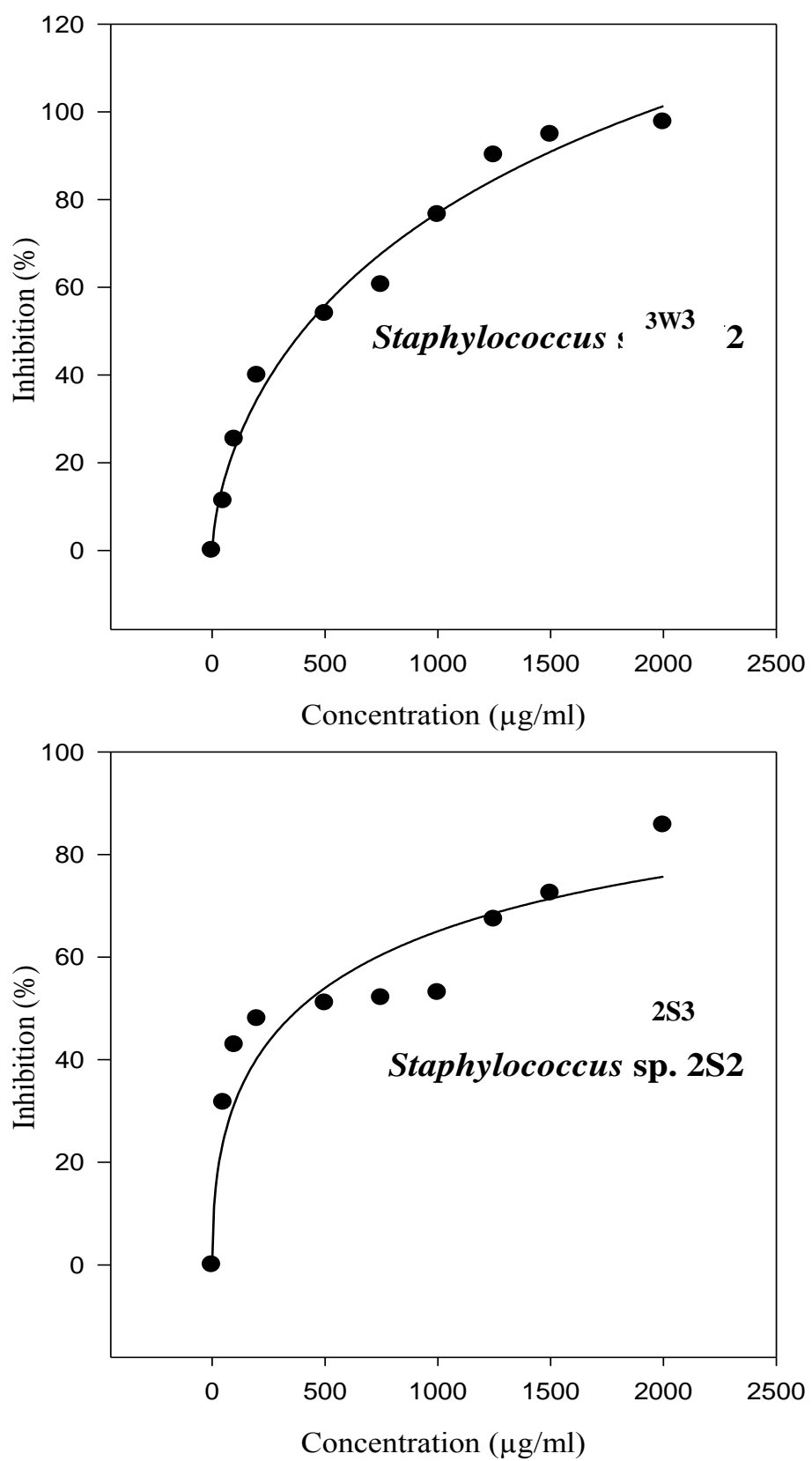

Figure 4.4:- Inhibition of dehydrogenase activity of Staphylococcus species $2 \mathrm{~S} 3$ from Quinine syrup and Staphylococcus species $3 \mathrm{~W} 3$ from injection water by cefixime. 

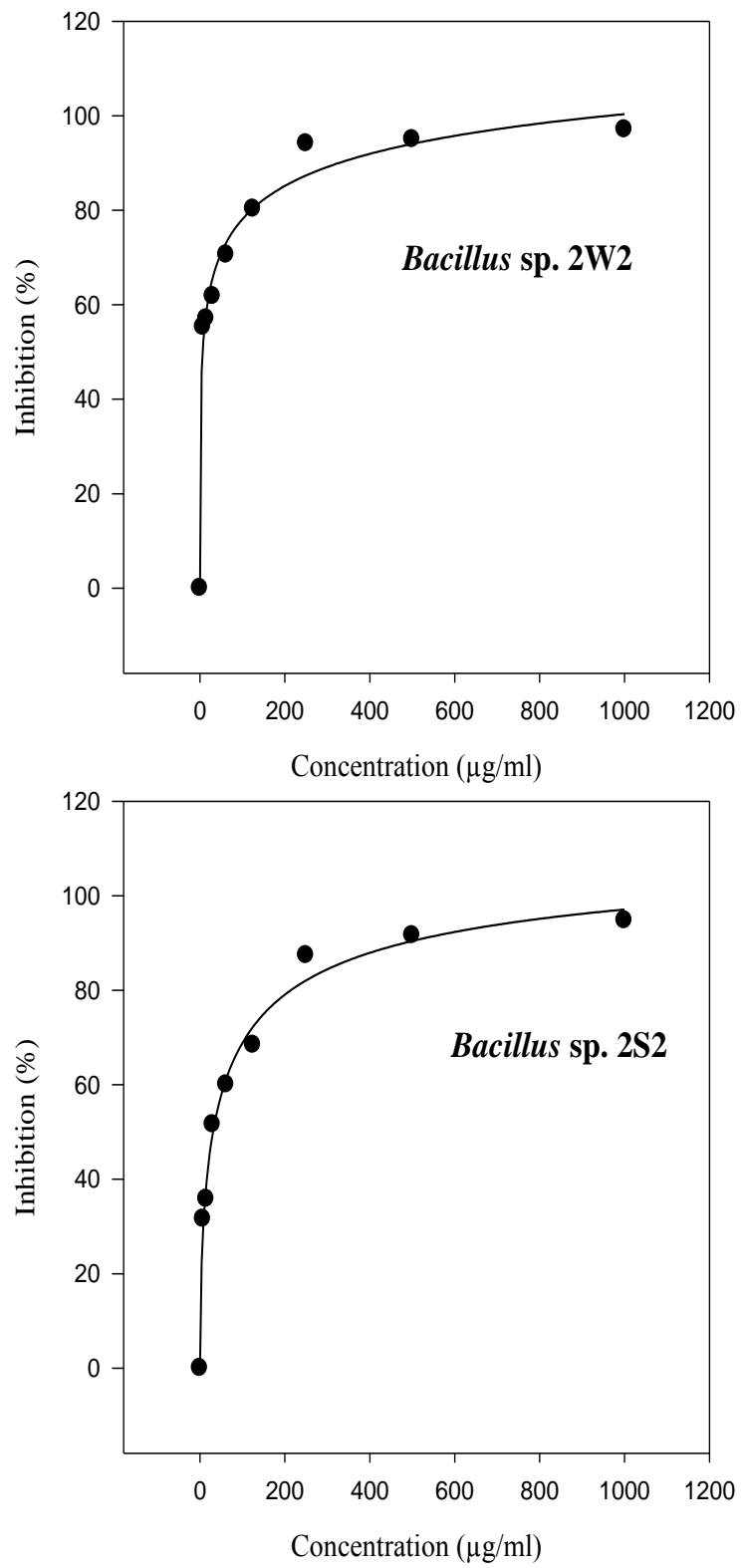

Figure 4.5:- Inhibition of dehydrogenase activity of Bacillus species 2S2 from Quinine syrup and Bacillus species 2W1 from injection water by Ciprofloxacin. 

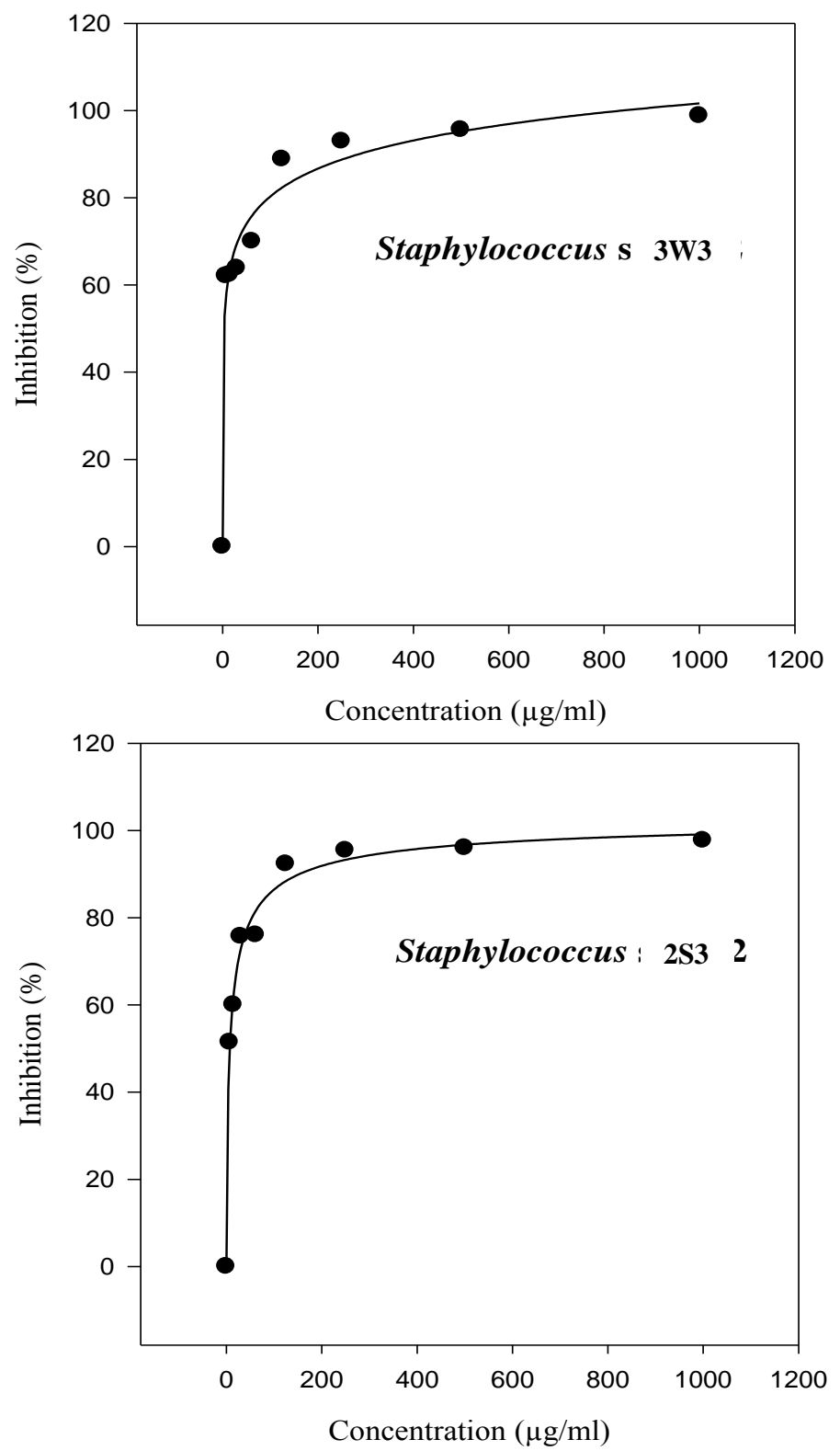

Figure 4.6:- Inhibition of dehydrogenase activity of Staphylococcus species 2S3from Quinine syrup and Staphylococcus species $3 \mathrm{~W} 3$ frominjection water by Ciprofloxacin. 

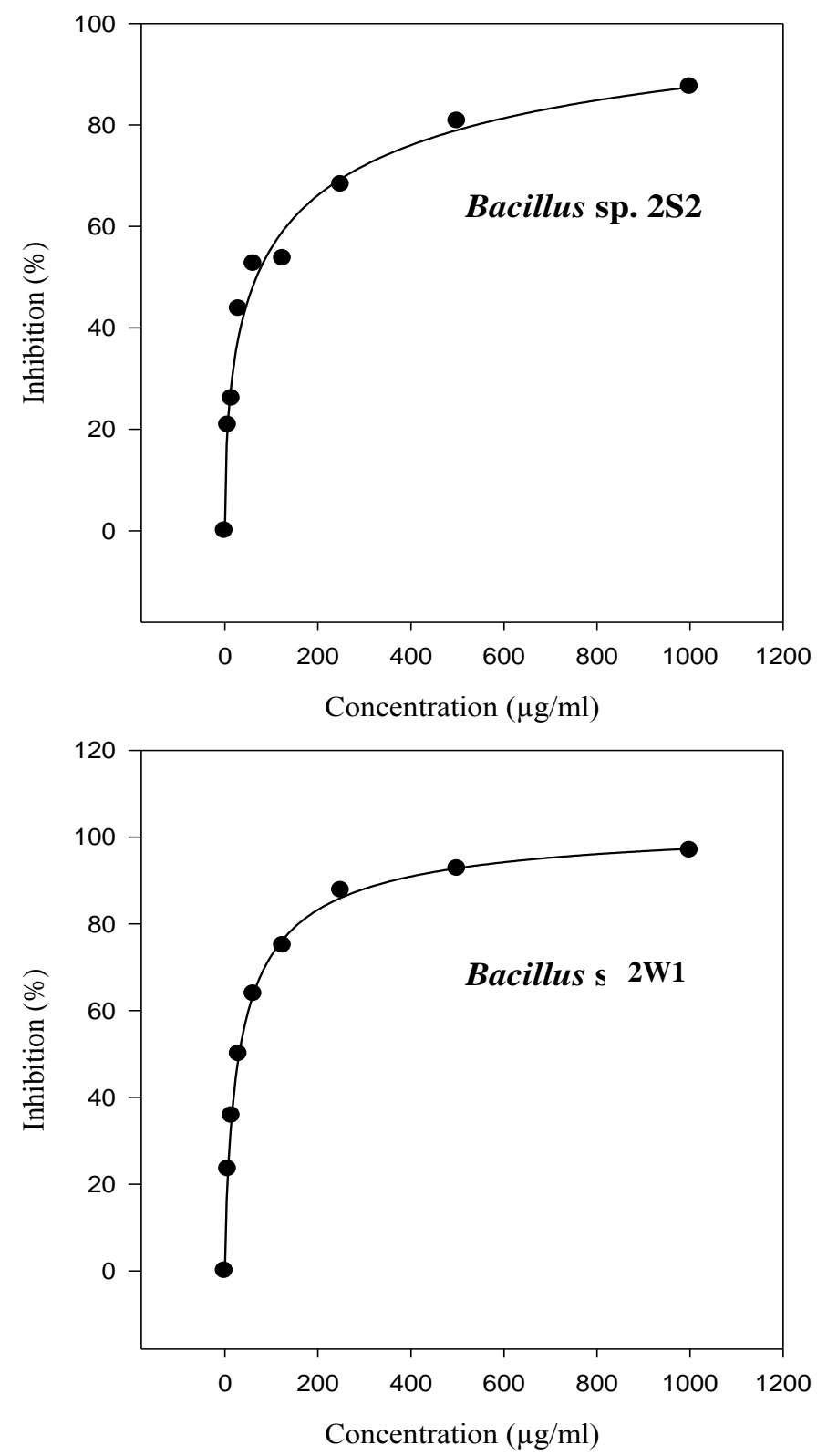

Figure 4.7:- Inhibition of dehydrogenase activity of Bacillus species 2S2 from Quinine syrup and Bacillus species $2 \mathrm{~W} 1$ from injection water by Levofloxacin. 

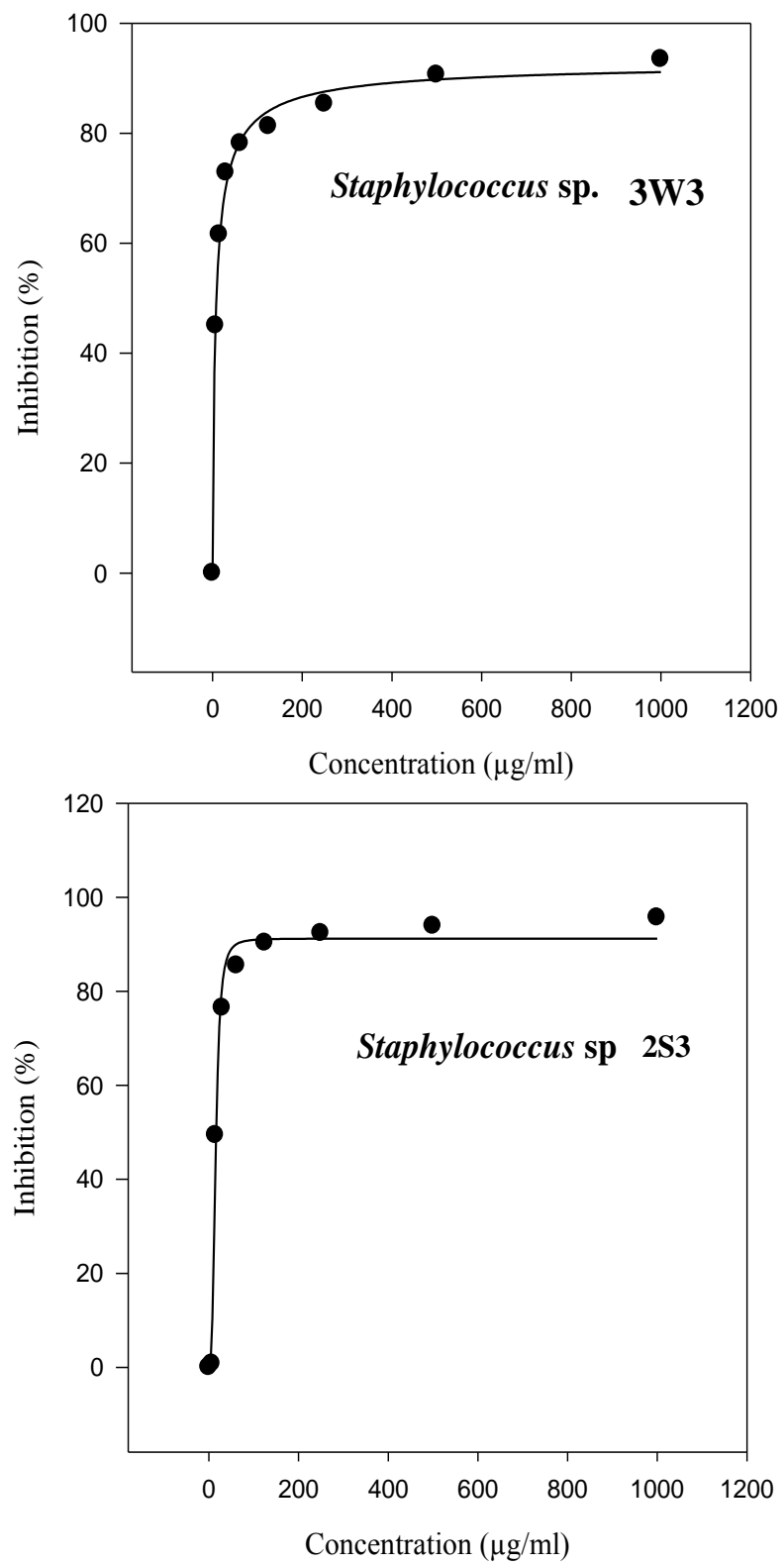

Figure 4.8:- Inhibition of dehydrogenase activity of Staphylococcus species 2S3 from Quinine syrup and Staphylococcus species $3 \mathrm{~W} 3$ from injection water by Levofloxacin.

\section{Discussion:-}

Microbial analysis was carried out on 20 quinine syrup and 10 Injection Water. The bacteria implicated in the samples were Bacillus species and Staphylococcus species. Although Kennedy et al., (2010) and Khanom, et al., (2013) in their work with quinine syrup and cough syrup found no organism during the analysis of their samples, Adeshina, et al. (2009) found Bacillus subtilis in their analyses of anti-malarial syrups. Also, Vessoni, et al., (2002) isolated Staphylococcus sp. and other microorganisms from purified water for the production of Injection water. In this study, Bacillus $s p$. was isolated from both the quinine syrups and water for injection. Isolation of Bacillus from pharmaceutical products has been reported. The presence of microbes may cause a significant deterioration in the health status of patients, particularly those who are immunologically compromised and of infants with immature immune systems (Nester et al., 2002). A higher microbial count was recorded in quinine syrup than injection water as shown in Table 4.1. Lower microbial count observed among few quinine syrup samples in this study conforms to the findings of Tukuret al. (2012). This may be attributed to the sugar content of the syrups which provides high 
osmotic pressure and this is inhibitory to many microorganisms and moreover, syrups are usually filtered before bottling (Tukuret al., 2012). The antimicrobial susceptibility pattern of Bacillus sp. and Staphylococcus sp. which were isolated from quinine syrup and Injection Water were screened for the reduction of 2, 3, 5-triphenyl tetrazolium chloride (TTC) was determined in this study and the result indicated that the organisms are good TTC reducers. The findings of this study have shown that all the samples tested were microbiologically contaminated. With regards to susceptibility test, both Staphylococcus sp. and Bacillus sp. from injection water showed higher susceptibility to Levofloxacin and Ofloxacin with the lowest MIC values of $0.025 \mu \mathrm{g} / \mathrm{ml}$ and $0.035 \mu \mathrm{g} / \mathrm{ml}$ of Levofloxacin to Staphylococcus sp. and Bacillus sp. and $0.050 \mu \mathrm{g} / \mathrm{ml}$ and $0.030 \mu \mathrm{g} / \mathrm{ml}$ of Ofloxacin to Staphylococcus sp. and Bacillus sp. They showed higher susceptibility to these antibiotics than the rest of the antibiotics used as shown in Table 4.7. For the syrup, Staphylococcus sp. was most susceptible to Moxifloxacin while Bacillus sp. was most susceptible to levofloxacin as shown in Table 4.6. Because of widespread drug resistance by organisms worldwide, the observed resistance of the isolated microbial contaminant to various antibiotics in this study underscores a need for immediate and stricter measures to address the issue of increasing rates of drug-resistant bacteria by adherence to proper usage of antibiotics in our communities. Ciprofloxacin with IC50 values of $52.63 \mu \mathrm{g} / \mathrm{ml}$ for the Bacillus species 2S2, $21.74 \mu \mathrm{g} / \mathrm{ml}$ for the Staphylococcus species 2S3 for Quinine syrup and IC50 values of $28.57 \mu \mathrm{g} / \mathrm{ml}$ for the Bacillus species 2W2, $13.51 \mu \mathrm{g} / \mathrm{ml}$ for the Staphylococcus species 3W3 for Injection Water are within the range reported by Nwanyanwuet al. (2018) on investigation of toxicity of quaternary mixtures of ciprofloxacin, ceftriaxone, ampicillin and gentamicin to clinical isolates of Escherichia coli and Staphylococcus aureus. They reported IC50 values of $8.16 \mu \mathrm{g} / \mathrm{ml}, 154.02 \mu \mathrm{g} / \mathrm{ml}, 16.23 \mu \mathrm{g} / \mathrm{ml} \mathrm{and}$ $2.05 \mu \mathrm{g} / \mathrm{ml}$ for Ciprofloxacin, Ceftriaxone, ampicillin and gentamycin on Staphylococcus sp. and $2.08 \mu \mathrm{g} / \mathrm{ml}$, $35.22 \mu \mathrm{g} / \mathrm{ml}, 82.11 \mu \mathrm{g} / \mathrm{ml}$ and $0.434 \mu \mathrm{g} / \mathrm{ml}$ of the same antibiotics on Escherichia coli. Water is one of the fundamental requirements of life and any undesired addition of chemical substance leads to its contamination and makes it unfit for human utility (Aloet al., 2012). Isolation of potential pathogens in injection water as recorded in this study is a matter of concern since preparations intended for parenteral or ophthalmic administration should be strictly sterile (Mwanbeteet al., 2009). However, isolation of bacteria from water for injection has also been reported by Mwanbeteet al. (2009) which is in line with the findings of this study.

\section{Conclusion And Recommendation:-}

In this study, quinine syrups and injection waters were assessed for their sterility. The results revealed high bacterial contamination of Bacillus species and Staphylococcus species. The results complement those of other studies that pharmaceutical products such as syrups and water for injection are devoid of microbial contaminations. However, these can serve as silent and unsuspected sources of infection in infants. According to the Parenteral Drug Association, during in-process quality control procedures, a sampling error of $1 \mathrm{cfu} / 10 \mathrm{ml}$ is an acceptable action limit, but if action limits are exceeded, then immediate action must be taken to rectify the problem. (Parenteral Drug Association, 1983). However, lower counts observed in injection water depicted the fact that injections should be sterile. The results of this study will serve as a benchmark in the production of syrups and water for injection which will be without microbial contamination.

This study has revealed that quinine syrups and Injection Waters that are commercially available in Owerri are microbiologically contaminated. Studies also showed that poor storage conditions of long shelf-life parentals may lead to decomposition of some ingredients in the formulation, resulting in $\mathrm{pH}$ change and ultimately, microbial contamination. (Hecht, 1995).

The isolation of potentially pathogenic opportunistic microorganisms such as Staphylococcus sp. and Bacillus sp. calls for more stringent measures during the production of the products as well as effective post-marketing surveillance. It is, therefore, recommended that the National Agency for Food and Drugs Administration and control should improve on its regulatory control of quinine syrup products, Injection Water especially their packaging before releasing them into the market to assure the safety of users.

\section{References:-}

1. Adeshina, G.O., Ajayi and Onaolapo, J.A. (2009).Microbiological quality of some commercially available paediatric antimalaria and cough preparations in Ilorin, Nigeria.Nigerian Journal of pharmaceutical Sciences, 8: 109-117.

2. Alo, M. N., Ayim, C. and Elom, M. (2012).Intestinal helminthiases in two rural communities in south-eastern Nigeria.Advances in Applied Science Research, 3:887-894 
3. Barennes, H., Pussard, E., Mahaman, S. A., Clavier, F., Kahiatani, F., Granic, G., Henzel, D., Ravinat, L. and Vendier, F. (1996).Efficacy and pharmacokinetics of a new intrarectal quinine formulation in children with Plasmodium falciparummalariae.British Journal of Clinical pharmacology.41(5):389-395

4. Center for Disease Control.(1991). Treatment with quinidine gluconate of persons with severe Plasmodiumfalciparuminfection.Morbidity and mortality weekly report.40(4):21-23.

5. Chapin, K.C. and Lauderdale, T. (2003). Reagents, stains, and media: bacteriology, p. 358.

6. Conn, H.J. (1975). Manual of Microbial methods. McGraw Hill, New York. Pp.37-72

7. FIP working Party (1975).Microbiological purity of non compulsory sterile pharmaceutical preparations.PharmaceuticaActaHelvetiae51:33-41

8. Friedel, J.K., Molter, W.R., Fisher. (1994). Comparision and improvement of methods for determining soil dehydrogenase activity by using TIC and TNT. Biology and fertile soil.18:29 1-296.

9. Hecht, G. (1995) Ophthalmic preparation. In Gennan AR.(Ed) Remington: The Science and practice of pharmacy ed 19, mack publishing Co Pennyslavia, pp1571

10. Kennedy R., Groepper D., Tagen M., Chrinstensen R., Navid F., Gajjar A., Stewart C. F., February 2010, Stability of c)clophosphamide in extemporaneous oral suspension, The Annals Of Pharmacotherapy. 44(2): 295 -301 .

11. Khanon, S., kantak., barite and Noor, R. (2013). Microbiological analysis of liquid oral drugs available in Bangladesh.International Journal of Pharmaceutical and Pharmacological Sciences, 5:479-482.

12. Mojekwu, J. and Ajilola, L. (2011).Developing a model for estimating infant mortality rate in Nigeria. Journal of research in international business and management, 1(2):164-170.

13. Mwambete, K.D., Justine, T.M and Fazleabas, F.S. (2009).Microbiological assessment of commercially available quinine syrup and water for injection in Dar Es Salaam, Tanzania.Tropical journal of pharmaceutical research, 8(5):441-447.

14. Nester, M. T., Anderson, D. G., Roberts, C. E. Jr. and Pearsal, N. N. (2002).Microbiology-A human perspective.Genitourinary Infections and Antimicrobial Medications. $3^{\text {rd }}$ ed. Madrid Spain: MacGrawHill Publishers.

15. Nwanyanwu, C. E. and Abu, G.O. (2012). Growth and degradation responses of phenol-utilzing bacteria to increased doses of phenol in petroleum refinery waste water. International Journal of Biosciences vol.2 10(1):125-134.

16. Nwanyanwu, C. E., Asiwe, E. S., Alisi, C. S. and Mbachu, I. A. C. (2017).Toxicity of quarternary mixtures of Ciprofloxacin, Ceftriaxone, Ampicillin and Gentamicin to Clinical Isolates of Escherichia coli and Staphylococcus aureus. Futo Journal Series(FUTOJNLS), 3:161 - 172

17. Nweke, C.O., Alisi, C.S., Okolo, J.C., Nwanyanwu, C.E., (2007). Toxicity of Zinc to heterotrophic bacteria of tropical river sediments.Applied Ecology and Envronmental Research, 5(1):123-132.

18. Rich, P.R., Mischis, L.A., Purton, S. and Wiskich, J.T. (2001).The sites of interaction of triphenyltetrazolium chloride with mitochondrial respiratory chains.FEMS Microbiology Letters, 202:181-187.

19. Toure, Y. (2001). Malaria in Africa, emerging prevention and control strategies. Report from a Symposium at the AAASannualmeeting.SanFrancisco.

20. Tukur, M. A., Muazu, J. and Mohammed, G. T. (2012). Microbial analysis of brands of multivitamin syrups marketed in Maiduguri, Northeast Nigeria.Advances in Applied Science Research, 3:3124-3128

21. Vessoni, T. C. P., Silva, A. M. M. and Priscila, G. M. (2002). Identification of bacteria in drinking and purified water during the monitoring of a typical water purification systemBMC Public Health2:13, pp 1471-2458.

22. WHO, (2003).Guidelines for drinking-water quality, 3rd edition. Geneva, World Health Organization. Pp.4058. 